\title{
HOW DIGITAL TECHNOLOGIES ARE CHANGING SPORT?
}

\author{
${ }^{1}$ Rathonyi, G., ${ }^{2}$ Bácsné Bába É., ${ }^{3}$ Müller, A., ${ }^{4}$ Rathonyi-Odor K. \\ University of Debrecen \\ ${ }^{1}$ Department of Agricultural Informatics 4032 Debrecen, Böszörményi 138. \\ 2,3,4 Department of Sporteconomics and Management 4032 Debrecen, Böszörményi 138. \\ rathonyi.gergely@econ.unideb.hu \\ bacsne.baba.eva@econ.unideb.hu \\ müller.anetta@econ.unideb.hu \\ rathonyi-odor.kinga@econ.unideb.hu
}

\begin{abstract}
Sports is considered to be an outstanding sector of industry all over the world and can be defined in various fields from business point of view: for example competitive sports, recreation, fitness and entertainment (running commentary). All of these areas have been remarkably transformed by digital technology. Over the past three decades, the discipline sport informatics has become a growing discipline. In today's connected world, the use of wearable technology, big data analytics, social media and sensor technology have revolutionized the way sports are played, analyzed and improved. Through various modern advances and apps, pro athletes can gain greater insight into their performance, improve training methods and elevate their skills. In addition to these, fans looking for mobile-friendly apps to give them the latest stats on the favorite players; real-time, behind the scenes content coupled with the instant reaction, from athletes and fellow fans alike. They want the highs, the lows, the remix replays, seeking a connection beyond the game and looking to share the experience with like-minded fans in the moment (WESTON, 2018). The aim of this present study, on the one hand, is to determine the interlocks of sports and information technology, on the other hand, to show how to increase fan experience with digital technologies under-propping them with practical examples. According to international literatures, there are 4 macro areas which show the linking between sport and informatics: athletic performance, sport club, event management, fan experience. Mobil fan experience, augmented (AR) and virtual reality (VR), big data, social media are those technologies which even popular are these days in order to enhance fan experience in sport.
\end{abstract}

Keywords: Sport Informatics, Fan Experience, Mobile Experience, Virtual Reality. (JEL Classification: L83)

\section{INTRODUCTION}

In the last 10 years, computer science has become an important interdisciplinary partner for sport. Applications of computers in sport have been reported as early as the mid1960's (SYKORA et al. 2015).

In 1975 in Graz a congress was organized by the International Organization for Sports Information (IOSI), where members created and defined the term "sports informatics" (BACA, 2006). According to that, sports informatics covers activities ranging from the most basic to the most complicated ones: from data handling and sensor control with simple tools to how to model and simulate complex phenomena. Interestingly, in the 1970s computers served as information and documentation tools only (LEVY and KATZ 2007), today however, the new methods and applications range has manifolded: virtual reality applications are a daily occurrence in sports commentary, top level sports is backed by VR technologies, in the training process e-learning features and bio-mechanical phenomena with VR modelling and simulations has also become possible as well as many other options (LINK and LAMES 2015).

Modern society experienced an increase in computer systems in almost every aspect in the 1980s. Experts discovered that the use of computer systems enable them to construct a strong system in computer processes and processes of the real world. Computer scientists dug themselves deeper 
and deeper into understanding these interactions and therefore applied approaches and methods from behavioral and social sciences, such as sport science (LINK and LAMES 2009).

Computer science has grown to be a widely appreciated science in all fields of research and as a result of this, new research fields have appeared from the cooperation of technical experts and specific domain experts: bio-informatics, neuro-informatics and business informatics as well as sports informatics (LINK and LAMES 2015).

There are endless number of potentials for cooperation between computer and sports science (HÁHNER, 2016; LINK and LAMES 2015; STÖCKL and LAMES 2011):

- Sports scientists can take very good advantage of computer science services in special technological areas, such as data handling and software development for training documentation, controlling sensors, visualizing data, and many more.

- It is important to pay attention to innovation in sports especially in training and competition. With the help of new technologies, sport activities can be supported and it is computer scientists that can help sports experts to become aware of these technological potentials.

- Preferably, computer science approaches and perspectives should apply to the fields of sports science. For instance, soft computing concepts can support the comprehension of phenomena in sports.

- Today it is impossible to run a sports event without exhaustive statistics and an abundance of figures in order to provide fans with information about their favorite teams or athlete real time - that is during the broadcast - on the spot (BODACZ, 2015). Technological development broadens the opportunities of amateur athletes, as well.

As we can see above, sport informatics is a reasonable and fruitful liaison between sport science and computer science. Common projects hold a set of advantages for both disciplines.

In our study we try to answer the following questions that our paper can articulate:

1. In what fields can sports and information technology interlock?

2. How can digital technologies support the increase of fan experience in a sports event or during a live commentary?

\section{MATERIAL AND METHODS}

To interpret how computer science has become an important interdisciplinary partner for sport, we relied on international special literature (BACA, 2006; LINK and LAMES 2009; LINK and LAMES 2015; STÖCKL and LAMES 2011; SYKORA et al. 2015).

In the presentation and grouping of the linking between sport and technology we trusted on the one hand international and Hungarian publications and researches, on the other hand we applied a comparative analysis based on secondary databases. With the help of data gained from clubs web sites, reports, case studies we analyzed how information and communication technology plays even bigger role in different part of sport (DE WEAVER, 2016; DE FREMERY, 2018;
INTERNET 8, 9, 13, 14, 15, 16; WESTON, 2018; ZSÉDELY, 2016a,b).

\section{RESULT AND DISCUSSION}

\subsection{The linking between sport and informatics}

There are 4 areas which show the linking between sport and informatics:

1. athletic performance,

2. sport club,

3. event management,

4. fan experience.

Following, we would like to present 3 areas briefly and in the next chapter we pan out about fan experience.

\section{Athletic performance}

This area is probably the most influenced by technology, since in this sector, the search of technologies that could help in the performance has been always carried out. This category focuses on the athletes, their coaches, the technical staff and the strength and conditioning staff. In addition to these, from the analysis of game and trainings performance other possible stakeholder could be the talent scouts, interested in finding new promises (FACCHINI, 2017).

Thanks to the increasing use of IoT (Internet of Things) technologies such as sensors and wearables and analytical tools in sport, different kind of data (athlete and team performance data etc.) have increasingly accessible, traceable, and visible not only for athletes and the coaching stuffs, but for the public as well (DAVENPORT, 2014; XIAO et al., 2018).

The use of accelerometers, gyroscopes, magnetometers, GPS, allow to get data that are very helpful to analyse performances, avoiding spending a lot of time analysing video as before was done. The main advantage of these tools are e.g. they are very small sizes and could be worn by athletes without minimal impediment in the classical activities and movements during the training sessions. (FACCHINI, 2017).

Wearables are even more important to athletes these days. To collect information for analysis, they track everything from the athlete's heart rate to body chemistry. Specialised wearables for boxers, basketball players or volleyball players who do lots of rope jumping during their training help them measure and improve their performance (INTERNET 6).

There are three main application areas of technologies, mainly differentiated by the finality and the aim in the use of them (INTERNET 5; 6):

- performance measurement,

- training,

- health and rehabilitation.

\section{Sport club}

From the point of this view, the sport club is a common firm, for this reason has been coined the term "sport firm". The most important impact of information technology on 
sport organisations is the advancement of physical equipment, hardware and software solutions. The most direct impact is that sports digitalization integrates lots of administrative functions into a comprehensive ICT service with multiple channels such as websites and mobile applications (XIAO et al., 2018). We can see, that with the help of technologies the club can get data various type, the decision making within the club has many more information to considerate.

Digitalization can help club in a different fields:

- infrastructure and security management,

- talent scouting,

- team management,

- sponsorship and supplier management.

Digitalization extends the ecosystem of sport organizations, as new IT stakeholders, such as software providers and data providers. For instance, the success of the German national soccer team in utilizing data analytics in the World Cup tournament was largely supported by software provider SAP (XIAO et al., 2018).

The talent scouting system has also been revolutionized. With the availability of huge amount of statistics created by different sensors wearables and analytical tools, lead that scouting and recruitment of players even more depend on data, instead of intuition and on eyes (STEINBERG, 2015; XIAO et al., 2018).

\section{Event management}

The events are the main point in sport. The sport club needs to manage a several games, optimizing the value it can create for fans and maximizing the returns they can get from them (FACCHINI, 2017). For sport firms digitalized sport consumption products are great opportunity to deliver their contents and services in customised way (HOYE et al., 2015). Therefore sports consumption products are not limited to only match-day events any more. Digitalization allows sport firms to become connected with the fans all over the world on a daily basis, with the help of different online channels (social media) and can share all organizational processes like training, new signings etc. (XIAO et al., 2018). Consequently all member of the organization from the fans to the president can be part of the distribution of content.

As far as referees, linesmen, umpires and other adjudicators are concerned - systems such as Decision Referral System (DRS), Hawk-Eye, Hot-Spot, Shot-Tracer, Radar Gun and Snick-O-Meter - innovative information technologies can help them to deliver a fair and unbiased experience in the sport (INTERNET 7).

The operations in which this area is subdivided are (INTERNET 4, 5, 9):

- events organization,

- stadiums and facility management,

- cultural promotion,

- referees support.

\subsection{Fan experience}

One of the most important group in the world of professional sports is its consumer, with other words the masses of spectators at the scene of the events, at home through TV broadcast or supporters on social media. That is the reason why the observation of passive or spectators' sports consumption has won a central role in the interest of international experts concerning the different aspects of sports marketing.

Supporters or fan groups are driven by different motives to watch a sports event live or through TV commentary. Researchers have been looking into motivation behind passive consumption and how this motivation changes in time and space. For example, MADARÁSZ (2018) presented that men are interested in sports events and quality while women are rather interested in show elements and programs related to the sports events. This has been especially interesting after sports became a branch of business and technological innovations became part of the sports world to a great extent. For sports associations and individual sportspeople functioning on professional basis it has been even more important to learn and understand the motivations of different consumption segments. These are certainly crucial because of revenue.

The bases of supporter motivation theories have been derived from previous, not only sports related theories. In the field of sports consumption motivational studies have been extended to consumption through media as well as the purchase of brand products apart from taking part in sports events (FILLIS and MACKAY 2014, FUNK et al. 2002, KAJOS et al. 2017).

In this chapter we would like to present how digital technologies are changing opportunities of fans and how these technologies enhance fan experience.

In the last decades digital technologies are dramatically changing the concept of fan experience. The traditional meaning of "fan experience" was about people enjoying watching matches at the stadium or at least on TV, organizing meetings with friends at game time (FACCHINI, 2017).

These days, clubs and stadiums need to form innovative business models and marketing strategies so as to remain competitive on the pitch and out of it, since an ever-growing generation of supporters grow up in the digital world. For the "digital natives" especially the digital offer of a club will be vital in whether or not they will become supporters and loyal to a club in the long run (INTERNET 1).

Nowadays we can easily access the live performance data, and it is therefore a good opportunity for sport organisations to use this availability for fan engagement (enhancing matchday experience) and commercial purposes (KLUG, 2015). Nowadays even more fans like to be hyper informed about daily news, to be always in touch with the favourite team, to listen impressions and interviews of athletes and coaches, to see how players are performing (INTERNET 3).

Next, we present some of those technology which even popular are these days in order to enhance fan experience in sport.

The mobile fan experience have already arrived in sport. Sports apps are bringing digital into the sports industry 
to improve the real-life experience of the game. In 2010, around $18 \%$ of searches around big sporting events were from smartphones. In 2016, it was $83 \%$ and it's only going in one direction (WESTON, 2018). Many soccer, basketball, and hockey teams have invested into apps for fans (INTERNET 2, INTERNET 13).

\section{Application examples}

- In the Hungarian football community DVSC introduced the popular supporters' application Seyu - Together for victory! in their matches. With this DVSC took a pioneering role to widen the match-day experiences of supporters. In Debrecen a great number of supporters use the popular application as Seyu is available on the matches of DVSC women's handball team, too. Supporters encouraged the girls with their pictures in the women's junior handball world championship held in July, too (INTERNET 15).

- Together with Microsoft, Real Madrid developed a mobile app. If we are at the stadium we can watch from different angles, or order food without leaving our seat. On nongame days we can still get personalized stats, purchase merchandise and a lot more. They have proven that an app can interact on a personal level and satisfy our needs by offering special sponsored deals just for us (INTERNET 9).

- Manchester United is betting big on mobile fan experience: apart from the standard app for fans, they have recently released a subscription-based live streaming app. MUTV offers live broadcasts, pre- and post-match commentary from MU's legends, video live streaming from Jose Mourinho press conferences, and more (INTERNET 13).

- FC Barcelona's mobile app provide news, game media, team statistics, game calendar, and more for fans in one place. This sports app also includes a mobile store and takes on the ticketing app duties. The fans are able to order a tour of the team's home stadium, Camp Nou, and Barca's museum (which connects Barcelona's m-commerce and e-commerce platforms). The app also has a clean, intuitive design that's easy on the eye. From 2015, FC Barcelona started out by offering QR-code electronic tickets to their fans via Passbook or PassWallet (INTERNET 14).

- The American Football team, New England Patriots, created 'the Patriots' app' which is one of the most featurerich sports apps available, delivering on the promise of a new, more modern and affecting fan experience. This mobile app keeps fans informed and engaged in four vast sections: (1) News \& Media, where fans can read the latest news and articles on their team; watch various videos and listen to team-related podcasts; and thumb through different photo galleries. (2) Season and Team deal with team statistics: game schedule, team standings, team statistics and all other numbers can be found here. (3) Game-day and Cheerleaders. Here we can find live chat, game center, and game highlights while the second is similar to team section, only smaller. (4) The Fanzone is the biggest sections: it includes everything from mobile store and sticker keyboard to wallpapers and instant feedback form (INTERNET 13).
- The hockey team, Grand Rapids Griffins' app covers all the essentials: team roster and game schedule; game media and news; tickets and mobile store. Griffins' sports app successfully captures hockey's power to entertain, delivering an engaging and rewarding fan experience that is in line with hockey aesthetic, as well as properly leverages gamification and the latest tech. There is a Photocard section in the app as well, where fans can take a photo in a present frame to become a Griffins' player, stand alongside the team's mascot (INTERNET 14).

- The NBA has embraced mobile technology in recent years, aiming to provide a personalized mobile fan experience. Apps provide convenient real-time information about open parking spaces to streamline fans' arrival at the game. With the help of this app, fans have increasingly been using mobile tickets to enter the stadium. In order to providing better security for the arena and easier transfer or resale options for fans, these apps also allow basketball enthusiasts to buy food, drinks and merchandise once inside the stadium. Some apps even give real-time information on bathroom and food service lines, making it even easier to enjoy the experience without any inconveniences (DE FREMERY, 2018).

Up to recently, coaches applied video footage to prepare for matches and train their players. They studied athletic performance from a few aspects, now, however, Virtual reality (VR) has widened the possibility of these aspects immensely, because it can visualize games with virtual fields, therefore games can be played on screen before they actually happen.

3D simulators enable players to choose from a number of tactical options and try their strategies multiple times against the opponents. The simulation is so sophisticated that it can create the same emotional pressure that an athlete goes through during a tournament. They can even experience the sensation of a jump that they have never tried beforehand (INTERNET 6).

Whether it is about developing player performance or giving fans a better viewing experience, Virtual Reality is always an excellent tool both on and off the field. It gets supporters closer to the game both on the scene and in front of the monitors at home. FOX Sports in joint venture with NextVR have broadcast live sporting events applying VR technology, winning such success that they were able to sell tickets on peak prices. It is probably the best proof that VR technology contributes and will contribute to the involvement in the future (INTERNET 3).

Augmented reality (AR) is a further step in technology: it projects a layer of information on the visible performance of a player supported by smart algorithms. In the future this could add extra knowledge to the field player with live information telling about the opponent's possible next move having observed his previous game data (INTERNET 6).

Various Virtual Reality companies can proudly name different NFL, NBA, NHL, NASCAR, MLB and college sport franchises, as well as media organizations as their clients. All those franchises have been "sold" on the idea of Virtual Reality as a new tool to improve their results 


\section{(INTERNET 10).}

\section{Application examples}

- In 2017, for the first time, BT Sport streamed the Champions League final live in 360 VR on YouTube and BT Sports apps. This was a unique experience for the fans, bringing them closer to the action than ever before. Fans could choose their own view of the final, direct from mobile (or VR headset), giving them access to live footage which was not available on the TV (INTERNET 8).

- The Minnesota Vikings have upgraded the old-fashioned sports museum experience into something more exciting and high tech. 10000 square feet of a trip through history in VR couldn't be more fan interacting and interesting (INTERNET 9).

- In September 2017 the Major League Baseball has launched an AR app MLB at Bat. The user just needs to point the mobile device towards the field and on the screen, he/she will see all player's statistics. Moreover, the information about the speed and the trajectory of every hit will also be given (INTERNET 11).

- The basketball team of FC Barcelona have run several tests with Google Glass technology: snapshots have been made both in the highly prestigious European cup series (Euroleague) matches and the trainings and later these various "viewpoints" where shared with the fans. Thanks to this innovation, supporters now have the chance to observe matches from the angle of their favourite player or may take a seat on the bench of their favourite team and can follow the play from the coach's eyesight simultaneously with the real time statistics of the match and the players (INTERNET 1).

The presence of social media has had a huge influence on every aspect of our lives in the past ten years, and sports is no exception either. Social media has altered the interaction between sorters, clubs and supporters greatly. Today a tight connection between sports events and social media is undoubted. Most teams, championships or sports associations run at least one media profile (Twitter, Facebook, Instagram, Youtube etc.) where they inform their fans and announce all important information. During any large-scale sports event we can find a number of references on the timeliness of the programs on these interface. Basically all sports events have so-called hashtags (e.g. \#finabudapest2017, \#avizosszekot), which create a meeting point and a quick way to interact for the viewers. Sportspeople use social media for self-marketing, communication with supporters, any announcements and advertising brands, taking advantage of the fact that they might have up to millions of followers. For supporters, social media provides a unique chance to trace results, communicate with other supporters or contact their favourite sportsmen, which would not have been possible a few years ago. Mobile technology gave an even greater impetus to the use of social interface and made it possible for more and more people to access contents independent of place (INTERNET 16).
By employing social media ever more intensively, clubs and players can target supporters, who cannot be achieved by strategies currently applied in social media.

Social networks such as Facebook, Twitter, Snapchat and WeChat have played a key role in this change that fans don't have to go to a game or rely on linear TV broadcasts to follow the action (INTERNET 8).

Facebook has indicated that there are more than 500 million soccer fans on the platform, many of whom will follow the top teams in the Premier League and LaLiga, but few of whom will ever be able to watch a game live in the stadium (INTERNET 8).

\section{Application examples}

- Online real time commentaries provide excellent opportunities for football supporters to interact on social interface. The sights of clubs on social media interface have become one of the most popular ways of searching for information on their team (results, events, news). Social network also gives the best opportunities for them to get closer to their favourite players, stars and to get more and personal information about them. These social sights feature quite a few exclusive data only accessible on these pages, e.g. short videos of matches, interviews, and trainings. On various forums they can discuss the performance and development of a team or a certain athletes with supporters of similar interest. One of the most significant advantage of social interface is that it is able to forward information to the target group incredibly quickly, therefore sportspeople and clubs like to use it for their sports campaign (INTERNET 1; INTERNET 3).

- Real Madrid has 104.7 million, FC Barcelona 102.8 million, Machester United 73.7 million fans on Facebook. One of the most popular athletes is Christiano Ronaldo who has 54.5 million followers on Twitter and 82.9 million on Istagram. Lebron James has 37 million follower on Twitter and 62.6 on Instagram (INTERNET 16).

- The NBA has a Facebook Messenger chatbot that can show highlights of specific players and top plays, delivering clips of the action in real time. Using new technology developed by Israeli startup WSC, the NBA can even automatically generate custom clips for certain types of plays and players (DE FREMERY, 2018).

Big data is a term that has been thrown around marketing and business circles over the last ten years. We can interpret big data as the massive volumes of 'data sets', found outside the firewall of any brand, sporting team or organization. These data sets are often very large, so while collecting them and making sense out of them makes sense, gleaning useful insights can be very challenging (DE WEAVER, 2016).

Among other industries, sport marketing takes advantage of big data on a daily basis. Top athletes or celebrities are keenly invited to promote brands as a method in sports marketing. Big data provides target consumers with information on their favourite players, or teams or the certain sports event they are looking for. A good example is a sports memorabilia store selling Atlanta Falcons gear in and around the city of Atlanta, 
where - with the help of big data storage - it is easy to find the supporters of the team, and the company can reach them to advertise their products or forward information on the team. Knowing the customers of this shop, it is even possible to find extra information on their shopping habits and interests: who are the most popular players among them. When it turns out, the company can make an agreement with that certain player to advertise their goods and wear the logo or name of their brand on their garment in matches (INTERNET 12).

There are two technologies concerning data that have a serious impact on sports industry: data analytics and the internet of things. The former gives way to professional sports organizations to observe and examine a vast amount of data that has been gathered by so-called special field cameras fixed to players' shoulder pads. With the help of these data analyses the doors open up for players' skill sets, discover yet aside talents, focus on team weaknesses to be developed and choosing the right starting players for kick-off in support of team victory. Lots of other potentials are present in these data analyses that is new research will be done in new fields.

The other data-technology is Internet of Things. This technology is able to collect and analyze data that are withdrawn from an incredible number of network-enabled devices.

Live cams on helmets afford coaches a bird's eye view of the game and wearable devices record players vitals and monitor them over time. Also, mechanisms are being installed in basketballs and soccer balls measure and record precise shooting and passing accuracy and to measure impact, spin and trajectory respectively (INTERNET 4).

\section{Application examples}

- In 2016 Amaury Sport Organisation (ASO) responsible for organizing the Tour de France in cooperation with Dimension Data information technology firm set up an online platform which offered special contents for the secondary monitor that is for mobile phones, tablets or computers to complement TV broadcasts. Race Centre is an online application that is stored in a Dimension Data cloud and was created in cooperation with ASO. Apart from the Tour de France live race data, extra videos, photos, commentary and social media news streams not included in the TV broadcast were also available on the platform. In addition to that, a "Live Tracking" page was launched for the time of Tour de France, where data on all the 198 racers of the 22 teams was available real time: their speed, the distance between them, the wind direction, the wind speed, or the weather conditions (ZSÉDELY, 2016a).

- In 2016 Microsoft became the official technological partner of LaLiga operating the two highest divisions (Primera División és Segunda División) of Spanish football. The artificial intelligence supports the work of LaLiga on several points. Firstly, the system helps calculate the viewer number expectancy regarding every match-day, secondly, it aims to serve the online content demands of supporters. To boost supporter interaction chatbots based on artificial intelligence have been introduced which ask questions from the users appropriate to the environment of the discourse in the online communication and give actual answers from the data in their databank. Moreover, player specific info-graphics are created from real time match data, and complex statistics are at hand to be browsed. To improve the digital experience of supporters, technologies of gamification are also used. For example, users can take part in online challenges, games, where they can collect points and virtual money redeemable to exclusive contents or gifts (ZSÉDELY, 2016b).

- US Sailing ran a session entitled 'SAP Sailing Technology Partnership' which was fascinating to attend. It clearly illustrated the importance of big data while competing in boat racing. SAP also identified customer and boating solutions to help: (1) Regatta organizations - simplifying the running of races and regatta's; (2) Sailors - to help analyse performance and to optimise real-time strategies for tides, winds, competition and more; (3) Fans and Spectators - to give global access and provide greater understanding of racing; (4) Media and Commentators to provide accurate, real-time and insightful analysis (DE WEAVER, 2016).

\section{CONCLUSION}

Computer science in sport is a well-established research and development field. The unique combination of sport science and informatics with the large application field of sports at any level provides great perspectives (LINK and LAMES 2015).

Our conceptual paper deals with the immersion of information technology's impact on sports, and we tried to present it as many aspect as possible. The main purpose of this article was to introduce the latest technologies in connection with fan experience throughout practical examples.

According to the four main areas, we have reviewed the latest trends linking between sport industry and informatics. Administration of sports, live broadcasting, business intelligent and analytics, mobile applications and social media are increasingly utilized in sport organizations. The huge amount of data generated by different digital means (wearables, sensors, analytical tools, cameras etc.) have increasingly accessible, traceable, and visible for all members of the sport organizations and for the sport fans as well. The importance of using data analytics is essential to improve the performance of athletes, teams and clubs. Consequently, using information technology creates competitive advantages for the sport organizations.

The most important group in the world of professional sports is its consumer. Digitalization have revolutionized the sport consumption and the supporter motivation behavior. Nowadays even more fans like to be hyper informed about daily news, to be always in touch with the favorite team, to 
listen impressions and interviews of athletes and coaches, to see how players are performing, in other words: stay connected.

Mobile technology enable fans to access relevant content, share their experiences on different social media sites during the event, and to get more customized experience.

All in all, we tried to show that researches in sportinformatics should not to be limited only for sport analytics, because digitalization has a great impact on all fields and members of the sport industry.

\section{Acknowledgments}

The publication is supported by the EFOP-3.6.2-16-201700003 project. The project is co-financed by the European Union under the European Social Fund.

\section{REFERENCES}

Baca A. (2006): Computer Application in Sports. In: Moritz E.F., Haake S. editors. The Engineering of Sport 6. Springer, New York, 2006: 185-190.

Bodacz P. (2015): Már sport sincs informatika nélkül. Permanent link to this document: https://mno.hu/gazdasag/ mar-sport-sincs-informatika-nelkul-1297192 Approached: September 2018.

Davenport T.H. (2014): Analytics in Sports: The New Science of Winning, International Institute For Analytics.

De Fremery R. (2018): How the personalized mobile fan experience has changed the game for NBA fans. Permanent link to this document: https://mobilebusinessinsights.com/2018/01/ how-the-personalized-mobile-fan-experience-has-changed-thegame-for-nba-fans/ Approached: September 2018.

De Weaver G. (2016): Big data + big ideas = big impact in sports marketing Permanent link to this document: http:// geoffdeweaver.com/big-data-big-ideas-big-impact-in-sportsmarketing-part-1/ Approached: September 2018.

Facchini L.V. (2017): Digital strategy in a sport club: a model to support the analysis. Master of Science in Management Engineering, Italy. 2017: 35-55.

Fillis I., Mackay C. (2014): Moving beyond fan typologies:The impact of social integration on team loyalty in football. Journal of Marketing Management, 30(3-4): 334-363., DOI:10.1080/02 67257X.2013.813575

Funk D., Mahony D., Ridinger L. (2002): Characterizing consumer motivation as individual difference factors: Augmenting the Sport Interest Inventory (SII) to explain level of spectator support. Sport Marketing Quarterly, 11(1): 33-43.

Háhner P. (2016): Robbanás a sportiparban: jön a hightech tömegrendezvények kora. Permanent link to this document: https://www.portfolio.hu/tool/print.php? $\mathrm{i}=241811 \& \mathrm{k}=3$ Approached: September 2018.

Hoye R., Smith A. C. T., Nicholson M., Stewart B. (2015). Sport Management: Principles and Applications, Routledge.

Internet 1: A foci sem kerülheti el a digitalis átalakulást. Permanent link to this document: https://www.pwc.com/hu/ hu/sajtoszoba/2014/foci digitalis atalakulas.html Approached:
September 2018.

Internet 2: Az Ericsson fokozza a szurkolói élményt. Permanent link to this document: http://brandtrend.hu/dizajn-esinnovacio/2016/05/31/az-ericsson-fokozza-a-szurkoloi-elmenyt Approached: September 2018.

Internet 3: 6 Ways technology is impacting the wide world of sports. Permanent link to this document: https://www.idtech. com/blog/how-technology-is-impacting-sports Approached: September 2018.

Internet 4: 21st-Century Sports: How Digital Technology Is Changing the Face of The Sporting Industry. Permanent link to this document: https://www.huffingtonpost.com/ sam-cohen/21st-century-sports-how-d_b_12039220. html?guccounter $=1$ Approached: September $2 \overline{0} 1 \overline{8}$.

Internet 5: Technology Will Change the Future of Professional Sports! Permanent link to this document: https://medicalfuturist. com/technology-changes-the-future-of-professional-sports Approached: September 2018.

Internet 6: 4 ways in which technological innovation enhances athletic performance. Permanent link to this document: https:// www.richardvanhooijdonk.com/en/blog/4-ways-technologicalinnovation-enhances-athletic-performance/ Approached: September 2018.

Internet 7: How technology has started to impact and transform Sports. Permanent link to this document: https:// www.sportskeeda.com/sports/sports-technology Approached: September 2018.

Internet 8: Sport is changing and technology is shaping its future. Permanent link to this document: https://www. globalsportsjobs.com/article/sport-is-changing-and-technologyis-shaping-its-future/Approached: September 2018.

Internet 9: 6 "SMART" fan engagement tools for 2017! Permanent link to this document: http://promoovertime.com/6smart-fan-engagement-tools-2017/Approached: September 2018.

Internet 10: Virtual Reality in Sports and Sports Marketing. Permanent link to this document: http://promoovertime.com/ virtual-reality-sports-sports-marketing/Approached: September 2018.

Internet 11: Augmented Reality in Sports. Permanent link to this document: https://thinkmobiles.com/blog/augmentedreality-sports/Approached: September 2018.

Internet 12: How Big Data is Changing the Sports Marketing Industry. Permanent link to this document: https://www. linkedin.com/pulse/how-big-data-changing-sports-marketingindustry-patrick-morrisey Approached: September 2018.

Internet 13: The Mobile Fan Experience of Top Sport Teams, p. 2. Permanent link to this document: https://www.intellectsoft. net/blog/mobile-fan-experience-world-class-sport-teamspart-2/ Approached: September 2018.

Internet 14: The he Mobile Fan Experience of Top Sport Teams. Permanent link to this document: https://www.intellectsoft. net/blog/mobile-fan-experience-world-class-sports-teams/ Approached: September 2018.

Internet 15: Új szezon, új szurkolói élmény a Lokinál. Permanent link to this document: https://www.dvsc.hu/kiemelthirek/uj-szezon-uj-szurkoloi-elmeny-a-lokinal Approached: October 2018.

Internet 16: The Huge Statistics of Sports on Social Media. Permanent link to this document: https://rosystrategies.com/ the-huge-statistics-of-sports-on-social-media/ Approached: 
October 2018.

Kajos A., Priszkóta Gy. Paic R. (2017): A nézôtéri sportfogyasztás motivációit mérô magyar nyelvű „SPEEDE-H” skála validációja és néhány eredménye. Vezetéstudomány/Budapest Management Review, 2017, 48(10): 19-31.

Klug W. (2015): A whole new ball game: how data and tech are changing sport. The Guardian, https://www.theguardian.com/ technology/2015/apr/09/how-data-and-tech-changing-sport

Levy R., Katz L. (2007): Virtual Reality Simulation: Bobsled and Luge. IACSS07, 6th International Symposium of the International Association of Computer Science in Sport Calgary: Canada, 2007: 241-251.

Link D., Lames M. (2009): Sport Informatics - Historical Roots, Interdisciplinarity and Future Developments. International Journal of Computer Science in Sport Vol. 8, Ed. 2.

Link D., Lames M. (2015): An introduction to sport informatics. In: Baca A. editor. Computer Science in Sport - Research and practice. Routledge research in sport and exercise science. 2015: 17-32.

Madarász T. (2018): Magyar sportsikerekben gazdag egyéni sportágak versenyképességi tényezőinek meghatározása fiatal sportfogyasztók megítélése alapján, PhD disszertáció, Debreceni Egyetem 2018.

Steinberg L. (2015): Changing the game: The Rise of Sports Analytics, Forbes, http://www.forbes.com/sites/ leighsteinberg/2015/08/18/changing-the-game-the-rise-ofsports-analytics.

Stöckl M., Lames M. (2011): Modeling constraints in putting: The ISOPAR method. International Journal of Computer Science in Sport, Vol. 10, No. 1, pp. 74-81.

Sykora M., Chung P.W.H., Folland J.P., Halkon B.J., Edirisinghe E.A. (2015): Advances in Sports Informatics Research. In: Phon-Amnuaisuk S., Au T. editors. Computational Intelligence in Information Systems. Advances in Intelligent Systems and Computing. Vol 331. Springer, Cham, 2015: $265-$ 274.

Weston J. (2018): How digital is transforming sports sponsorship Permanent link to this document: https://wearesocial.com/ blog/2018/05/how-digital-is-transforming-sports-sponsorship Approached: October 2018.

Xiao X., Hedman J., Chian Tan F.T., Tan C-W., Lim E.T.K., Clemenson T., Henningsson S., Mukkamala R.R., Vatrapu R., van Hillegersberg J. (2018): Sports Digitalization: An Overview and A Research Agenda. Thirty Eighth International Conference on Information Systems, 201An Overview and A Research Agenda. Paper presented at 38th International Conference on Information Systems 2017, Seoul, Korea, Republic of.

Zsédely P. (2016a): Egyedi digitalis élményt kínál a Tour de France. Permanent link to this documents: http:// sportsmarketing.hu/2016/07/01/egyedi-digitalis-elmenyt-kinala-tour-de-france/ Approached: October 2018.

Zsédely P. (2016b): A Microsoft segítségével alakítja át a LaLiga a digitális szurkolói élményt. Permanent link to this documents: http://sportsmarketing.hu/2016/12/05/a-microsoftsegitsegevel-alakitja-at-a-laliga-a-digitalis-szurkoloi-elmenyt/ Approached: October 2018. 